\title{
ESTIMATION OF SOME HEAVY METALS AND BLOOD PICTURE IN FATTENING BULLS IN ASSIUT GOVERNORATE
}

\author{
AHMED A. SHARKAWY ${ }^{1}$ and SAHAR A. ABOU-ELWAFA ${ }^{2}$ \\ ${ }^{1}$ Department of Forensic Medicine and Toxicology, Faculty of Vet. Medicine, Assiut University, Assiut, Egypt. \\ ${ }^{2}$ Department of Internal Medicine, Faculty of Veterinary Medicine, Assiut University, Assiut, Egypt.
}

Received: 2 March 2016; Accepted: 29 March 2016

\begin{abstract}
Environmental pollutants have hazardous impact on living organisms as they affect the health of livestock as well as human beings. They have been broadly categorized as heavy metals, pesticides and mycotoxins. Lead, and Cadmium, get deposited in the vital organs through the food chain. Blood being a major medium of transfer of heavy metals into milk and other tissues including meat. It is necessary to assess the levels of these metals in bull blood. Forty random samples of blood were collected from native breed fattening bulls from villages located nearby Assiut City, Assiut Governorate, Egypt were used in this study. Blood levels of lead, cadmium, copper and iron with Inductively Coupled Plasma Emission Spectrometer (ICP). Blood picture were estimated with automatic cell counter. This study revealed that blood levels ( $\mathrm{ppm}$ ) for heavy metals were ranged from 17.4977.00 for $\mathrm{Pb}, 0.0142-0.9625$ for $\mathrm{Cd}, 3.424-6.325$ for $\mathrm{Cu}$ and 385-614 for Fe. All estimated blood parameters were within the normal levels. In conclusion: Despite the presence of potential sources of environmental contaminants containing heavy metals, the level of these metals in the blood of bulls reached the alarming level and continuous monitoring should be done. Necessary action should have to be taken to avoid hazardous situation which may arise in future for betterment of next generation.
\end{abstract}

Key words: Blood picture, fattening bulls, iron, copper, lead, cadmium.

\section{INTRODUCTION}

Environmental pollution is the presence of a pollutant in environment such as air, water, soil and consequently in food which may be toxic causing harm to living things in the polluted environment (Duruibe et al., 2007). The excessive amount of pollutant such as heavy metals in animal feed and feedstuffs are due to anthrpogenic activity, resulting from either agriculture or industrial production or accidental or deliberate misuse (El-Beltagi et al., 2010).

Heavy metals are persistent contaminants in the environment that can cause serious health hazards. Some heavy metals (like copper, $\mathrm{Cu}$ and iron, $\mathrm{Fe}$ ) are essential to maintain proper metabolic activity in living organisms; others (like lead, $\mathrm{Pb}$ and cadmium, Cd) are non-essential and have no biological role (Qin et al., 2009; Kochare and Tamir, 2015). However, at high concentrations, they can cause toxicity to living organisms ( $\mathrm{Li}$ et al., 2005).

Corresponding author: SAHAR A. ABOU-ELWAFA

E-mail address: dsaharahmed2003@yahoo.co.uk

Present address: Department of Internal Medicine, Faculty of

Veterinary Medicine, Assiut University, Assiut, Egypt.
Excessively higher levels of these metals in blood and tissues of animals suggest an exposure either from the air, soil, water or feeds or all these sources (Farr, 2004). Contamination of animal feeds by toxic metals cannot be completely eliminated (SCAN, 2003).

Contamination with heavy metals is a serious threat because of their toxicity, bioaccumulation and biomagnifications in the food chain. These pollutants often have direct physiological toxic effects because they are stored or incorporated in tissues, sometimes permanently (Abd EI-Salam et al., 2013). The main sources of environmental $\mathrm{Pb}$ are from leaded gasoline, lead shots or bullets, soil, dust, toys, lead acid batteries, cosmetics and paints (Thuppil and Tannir, 2013). $\mathrm{Pb}$ is an environmentally persistent toxin that causes neurological, hematological, gastrointestinal, reproductive, circulatory, and immunological disorders (Patrick, 2006). $\mathrm{Cd}$ is primarily toxic to kidney, especially to proximal tubular cells. Bone demineralization is affected by $\mathrm{Cd}$ toxicity directly by bone damage and indirectly as results of renal dysfunction (Solidum et al., 2013). Cd induces nephrotoxicity, osteoporosis, neurotoxicity, carcinogenicity and genotoxicity, teratogenicity, and endocrine and reproductive effects (EFSA, 2009).

Iron and copper are essential micronutrient in animals and humans with well defined role in body 
metabolism though at elevated concentration could tend to be toxic (Ogabiela et al., 2011). Iron is an essential mineral needed to prevent anemia. Iron is generally abundant in cattle diets, but has an antagonistic relationship with some trace minerals, particularly copper. Copper is a critical element needed for many biological function ranging from metabolism of iron, which prevents the animal becoming anemic, to assisting with immune functions and reproduction (Whitehurst, 2015).

Cadmium and lead are classified as some of the dangerous heavy metals to health and environment. Therefore it is necessary to investigate the accumulation of heavy metals which are of public health importance in the blood and tissue of animals readily used as food. This study is aimed at determining the levels of selected heavy metals $(\mathrm{Pb}$, $\mathrm{Cd}, \mathrm{Fe}$ and $\mathrm{Cu}$ ) in the blood of fattening bulls from villages located nearby Assiut City, Assiut Governorate, Egypt, which serves as the largest supplying of meat and meat products to the people and their environments in this area.

\section{MATERIALS AND METHODS}

\section{[A] Materials:}

1- Animal: Forty random samples of blood were collected from native fattening bulls from villages located nearby Assiut City, Assiut Governorate, Egypt. The animals reared and fed predominantly on water, grasses, and feedstuffs grown in the studied area.

2- Blood samples: Blood sample was $10 \mathrm{ml}$ drained from jugular vein by means of sterilized disposable syringe into vaccumed tube with anticoagulant. The tubes were preserved in ice packed cold box and transported to laboratory. Half of each sample was used for blood picture and the second half was used for heavy metals $[\mathrm{Pb}, \mathrm{Cd}, \mathrm{Fe}$ and $\mathrm{Cu}]$ estimation.

Sample preparation for trace and heavy metals analysis: The method of Ataro et al. (2008) was adopted for digestion of liquid samples. One $\mathrm{ml}$ of whole blood was digested using $10 \mathrm{ml}$ concentrated $\mathrm{HNO} 3$ at $150^{\circ} \mathrm{C}$ for 30 minutes on digestion apparatus, until clear solution was obtained indicating the end of digestion. The digests were allowed to cool, filtered and then diluted to $25 \mathrm{ml}$ in a standard flask.

\section{[B] Methods:}

1- Blood picture: Different blood parameters [total red blood cell (RBCs); hemoglobin concentration (HGB), hematocrite (HCT); blood platelets (PLTs), total and differential leuckocytic counts; RDW (Red cell distribution width), MCV (Mean Corpuscular volume), $\mathrm{MCH}$ (Mean Corpuscular Hemoglobin), MCHC (Mean Corpuscular Hemoglobin Concentration), PLT (blood platelets)], lecucytic count and differential lecucytic counts in this study were done by automatic cell counter [Boule Medical AB Sweden Exigo Veterinary Hematological Analyser 1504374 jan 2013].

2- Metal Analysis: Metals concentrations were determined using the ICP [Inductively Coupled Plasma Emission Spectrometer (ICAP 6200)] Central laboratory for chemical analysis, Faculty of Agriculture, Assiut University.

3- Statistical analysis: The study evaluated the levels of $\mathrm{Cd}, \mathrm{Pb}, \mathrm{Fe}, \mathrm{Cu}$ and blood picture of bulls. Averages, mean, variances and standard error were determined. The results were expressed as the mean \pm SE. All data were analyzed using SPSS 11.0 statistical software (SPSS, Inc, Chicago, IL, 2001).

\section{RESULTS}

The obtained results in this study were summarized in tables (1-6). Table 1 showed that all levels of estimated metals $(\mathrm{Pb}, \mathrm{Cd}, \mathrm{Cu}$ and $\mathrm{Fe}$ ) were highly significantly increased than that of reference indicated values. Table 2 showed that there was only a correlation between $\mathrm{Pb}$ and $\mathrm{Cu}$ and Fe. Table 3 showed that there was no change between different blood parameters and the reference values. Table 4 showed a significant and highly significant correlation between investigated different blood parameters. Table 6 showed a significant and highly significant correlation between investigated differential leucocytes counts.

Table 1: Blood levels (ppm) of $\mathrm{Pb}, \mathrm{Cd}, \mathrm{Fe}$ and $\mathrm{Cu}$ in investigated fattening bulls.

\begin{tabular}{cccccc}
\hline Metal & Minimum & Maximum & Mean & S.E. & Reference value \\
\hline $\mathbf{P b}$ & 17.490 & 77.00 & $36.6825^{* * *}$ & 3.3837 & $0.250^{\mathbf{a}}$ \\
\hline $\mathbf{C d}$ & 0.0142 & 0.9625 & $0.1102^{* * *}$ & 0.0323 & $0.007^{\mathbf{b}}$ \\
\hline $\mathbf{F e}$ & 385 & 614 & $479.60^{* * *}$ & 9.4970 & $2.501^{\mathbf{c}}$ \\
\hline $\mathbf{C u}$ & 3.424 & 6.325 & $4.6780^{*}$ & 0.1101 & $1.500^{\mathbf{d}}$ \\
\hline
\end{tabular}

(a) Radostits et al. (2002), (b) Ogabiela et al. (2011), (c) Djokovic et al. (2014), (d) EMEA (2008).

*denotes $\mathrm{P}<0.05$ as compared to reference value.

*** denotes $\mathrm{P}<0.001$ as compared to reference value. 
Table 2: Correlation between the estimated metals $(\mathrm{Pb}, \mathrm{Cd}, \mathrm{Fe}$ and $\mathrm{Cu})$ in the blood of investigated fattening bulls.

\begin{tabular}{ccccc}
\hline & $\mathrm{Pb}$ & $\mathrm{Cd}$ & $\mathrm{Fe}$ & $\mathrm{Cu}$ \\
\hline $\mathrm{Pb}$ & 1 & .236 & $-.377^{*}$ & $.466^{* *}$ \\
\hline $\mathrm{Cd}$ & .236 & 1 & $-.088-$ & .023 \\
\hline $\mathrm{Fe}$ & $-.377^{*}$ & $-.088-$ & 1 & .071 \\
\hline $\mathrm{Cu}$ & $.466^{* *}$ & .023 & .071 & 1 \\
\hline
\end{tabular}

**. Correlation is significant at the 0.01 level (2-tailed).

*. Correlation is significant at the 0.05 level (2-tailed).

Table 3: Different blood parameters in investigated fattening bulls in this study.

\begin{tabular}{|c|c|c|c|c|c|}
\hline Blood parameter & Minimum & Maximum & Mean & S.E. & Reference value ${ }^{1,2}$ \\
\hline $\operatorname{RBCs}\left(10^{12} / \mathrm{L}\right)$ & 7.020 & 10.14 & 7.901 & 0.154 & $5-10$ \\
\hline HGB (g/dl) & 11.30 & 16.30 & 13.525 & 0.222 & $8-15$ \\
\hline HCT (\%) & 30.50 & 44.30 & 37.845 & 0.645 & $24-46$ \\
\hline MCV (fl) & 40.30 & 57.50 & 48.155 & 0.774 & $40-60$ \\
\hline MCH (pg) & 15.10 & 20.80 & 17.270 & 0.250 & $11-17$ \\
\hline MCHC (g/dl) & 34.30 & 37.80 & 35.875 & 0.131 & $30-36$ \\
\hline RDW (\%) & 21.20 & 25.90 & 23.305 & 0.206 & $0.0-99.9$ \\
\hline $\mathbf{R D W}^{\mathrm{a}}(\mathbf{f l})$ & 29.50 & 42.10 & 34.615 & 0.626 & $1-199.9$ \\
\hline $\operatorname{PLT}\left(10^{9} / \mathrm{L}\right)$ & 279.0 & 545.0 & 344.15 & 16.932 & $100-800$ \\
\hline MPV (fl) & 5.700 & 7.700 & 6.6125 & 0.096 & $0.0-80.0$ \\
\hline
\end{tabular}

(1) Plumb (2005), (2) Latimer (2011).

Table 4: Correlation between different blood parameters of investigated fattening bulls.

\begin{tabular}{lcccccccc}
\hline & RBCs & HGB & HCT & MCV & MCH & MCHC & $\begin{array}{c}\text { RDW } \\
(\%)\end{array}$ & RDWa \\
\hline RBCs & 1 & $.685^{* *}$ & $.620^{* *}$ & $-.485^{* *}$ & $-.505^{* *}$ & .153 & $.355^{*}$ & $-.418^{* *}$ \\
\hline HGB & $.685^{* *}$ & 1 & $.977^{* *}$ & .289 & .283 & $-.183-$ & $-.074-$ & .300 \\
\hline HCT & $.620^{* *}$ & $.977^{* *}$ & 1 & $.384^{*}$ & $.342^{* *}$ & $-.383^{*}$ & $-.137-$ & $.405^{* *}$ \\
\hline MCV & $-.485^{* *}$ & .289 & $.384^{*}$ & 1 & $.982^{* *}$ & $-.584^{* *}$ & $-.572^{* *}$ & $.940^{* *}$ \\
\hline MCH & $-.505^{* *}$ & .283 & $.342^{*}$ & $.982^{* *}$ & 1 & $-.421^{* *}$ & $-.557^{* *}$ & $.907^{* *}$ \\
\hline MCHC & .153 & $-.183-$ & $-.383^{*}$ & $-.584^{* *}$ & $-.421^{* *}$ & 1 & $.396^{*}$ & $-.602^{* *}$ \\
\hline RDW $(\%)$ & $.355^{*}$ & $-.074-$ & $-.137-$ & $-.572^{* *}$ & $-.557^{* *}$ & $.396^{*}$ & 1 & $-.272-$ \\
\hline RDWa & $-.418^{* *}$ & .300 & $.405^{* *}$ & $.940^{* *}$ & $.907^{* *}$ & $-.602^{* *}$ & $.272-$ & 1 \\
\hline
\end{tabular}

**. Correlation is significant at the 0.01 level (2-tailed).

*. Correlation is significant at the 0.05 level (2-tailed). 
Table 5: Different blood parameters determined in investigated fattening bulls.

\begin{tabular}{cccccc}
\hline Blood parameter & Minimum & Maximum & Mean & S.E. & Reference value $^{\mathbf{1 , 2}}$ \\
\hline WBCs $(\mathbf{1 0} \boldsymbol{9} / \mathbf{L})$ & 4.3 & 10.0 & 7.175 & 0.273 & $4-12$ \\
\hline Lymphocytes $(\mathbf{1 0} / \mathbf{L})$ & 1.6 & 4.0 & 2.495 & 0.101 & $2.5-7.5$ \\
\hline Monoctes $(\mathbf{1 0} / \mathbf{L})$ & 0.4 & 1.0 & 0.705 & 0.029 & $0.025-0.850$ \\
\hline Neutrophiles $(\mathbf{1 0} / \mathbf{L})$ & 1.4 & 5.5 & 3.605 & 0.197 & $0.6-4.0$ \\
\hline Eosinophiles $(\mathbf{1 0} / \mathbf{L})$ & 0.1 & 1.1 & 0.320 & 0.045 & $0.0-2.4$ \\
\hline Lymphocytes $(\boldsymbol{\%})$ & 23.1 & 48.2 & 36.275 & 1.333 & $45-75$ \\
\hline Monoctes $(\boldsymbol{\%})$ & 7.4 & 10.0 & 9.645 & 0.164 & $2-7$ \\
\hline Neutrophiles $(\boldsymbol{\%})$ & 34.2 & 62.7 & 49.225 & 1.336 & $15-45$ \\
\hline Eosinophiles $(\boldsymbol{\%})$ & 1.5 & 13.3 & 4.755 & 0.518 & $2-20$ \\
\hline
\end{tabular}

(1) Plumb (2005), (2) Latimer (2011).

Table 6: Correlation between different blood parameters of investigated bulls.

\begin{tabular}{cccccc}
\hline & WBCs & Lymphocytes & Monocytes & Neutrophiles & Esinophiles \\
\hline WBCs & 1 & $.527^{* *}$ & $.825^{* *}$ & $.923^{* *}$ & $.370^{*}$ \\
\hline Lymphocytes & $.527^{* *}$ & 1 & $.647^{* *}$ & .209 & $-.193-$ \\
\hline Monocytes & $.825^{* *}$ & $.647^{* *}$ & 1 & $.727^{* *}$ & .086 \\
\hline Neutrophiles & $.923^{* *}$ & .209 & $.727^{* *}$ & 1 & $.369^{*}$ \\
\hline Esinophiles & $.370^{*}$ & $-.193-$ & .086 & $.369^{*}$ & 1 \\
\hline
\end{tabular}

**. Correlation is significant at the 0.01 level (2-tailed).

*. Correlation is significant at the 0.05 level (2-tailed).

\section{DISCUSSION}

Environmental pollution has become a global issue and the results are implied in high level of contaminants reported for soil, water, air, plants and animals. Food items that constitute human diet are contaminated when they get in contact with polluted environmental media (Nwude et al., 2010b). Significantly elevated blood $\mathrm{Pb}$ and $\mathrm{Cd}$ levels in grazing animals alongside motor way when compared with control was recorded (Ward and Savage, 1994). Metals tend to bioaccumulate in the environment and biomagnified in food chains (Caggiano et al., 2004), their levels might reach toxic limits even when found in low concentrations in environmental samples. Since this should be limited to an unavoidable minimum, much attention is paid to the occurrence of these elements in food.

\section{Lead:}

Our obtained results in the study showed that lead levels (ppm) in blood were very high (36.6825 ppm) when compared with the normal values that mentioned by many authors (Radostits et al., 2007;
EMEA, 2008). Our results were supported by Ma (2011) who found that blood $\mathrm{Pb}$ level in a calf was (3.11 ppm) and Ogundiran et al. (2012) who found that $\mathrm{Pb}$ was detected in blood of animals was ranged from <0.080.0-1.380 ppm. This elevation may be attributed to [1] the drinking water admitted to these animals as drinking water is a major source of $\mathrm{Pb}$ exposure, even valves currently used in drinking water supply lines may contain 5-7\% leaded brass fixtures, have been shown to discharge $\mathrm{Pb}$ into drinking water, and constitute a significant source of $\mathrm{Pb}$ in the water supply (Sharkawy, 1991; Maas et al., 2002), [2] Ingestion of contaminated soils with lead. Direct ingestion of lead which causes increased blood lead levels, accumulated lead in the body also acts as a significant source of blood lead burden (Sharkawy, 1991; Swarup et al., 2005). Among the sources of $\mathrm{Pb}$ that have been found to cause $\mathrm{Pb}$ poisoning in livestock, the presence of large quantities of $\mathrm{Pb}$ in soils, sediments and/or water courses in areas of old mine workings has been frequently identified in cases diagnosed in grazing cattle (Payne and Livesey, 2010). [3] Ingestion of contaminated feeds with lead. Animal exposure to lead results mainly from feed and 
it is increased when feed materials contain significant amounts of contaminated soil. Cattle and sheep seem to be among the most sensitive animal species with respect to lead toxicities, and individual intoxications resulting from ingestion of feed material originating from polluted areas or accidental ingestions of lead sources including disposed batteries and other industrial waste have been reported (Sharkawy, 1991; EFSA, 2004). [4] Ingestion of contaminated plants. Plants can accumulate these metals in all parts leading to its transference through the food chain. The accumulation is today one of the latest topics of environmental interest due to its potential damage effects on animals and human health (Sharkawy, 1991; Juhasz et al., 2008). The elimination of lead is incomplete and slow, resulting in bioaccumulation in target tissues, especially after long term exposure. Its half-life is between 95 and 760 days in cattle (Rumbeiha et al., 2001).

Cows blood lead levels is a good bioindicator of environmental contamination (Sharkawy, 1991; Prpic-Majic, 1996 and Radostits et al., 2007). Red blood cells have a high affinity for $\mathrm{Pb}$ and contain major amount of circulating $\mathrm{Pb}$ (Leggett, 1993). Its sensitivity towards $\mathrm{Pb}$ is due to many factors such as $\mathrm{RBC}$ are exposed to high concentration of oxygen, $\mathrm{Hb}$ can be easily auto oxidized, $\mathrm{RBC}$ membrane components are vulnerable to LPO, and RBC's have limited capacity to repair their damaged components (Rice-Evans, 1990). Lead directly affects the hematopoietic system through restraining the synthesis of $\mathrm{Hb}$ by inhibiting various key enzymes involved in the hem synthesis pathway. It also reduces the life span of circulating erythrocytes by increasing the fragility of cell membranes these two processes leads to anemia (Guidotti et al., 2008).

Although adult cattle are primarily affected by $\mathrm{Pb}$ poisoning through the ingestion of polluted soils, plants and water, suckling calves are particularly vulnerable to suffer its clinical symptoms. Mean $\mathrm{Pb}$ levels detected in soils, plants and water were above the threshold values to be classified as highly polluted soils (Sharkawy, 1991), toxic pastures for livestock (Chaney, 1989 and Sharkawy, 1991), suggesting that cattle reared herein may be exposed to high levels of $\mathrm{Pb}$ pollution. Rodríguez-Estival et al. (2012) also detected the highest blood $\mathrm{Pb}$ levels in the two calves that they sampled from mining area (0.452 and 0.807 ppm, respectively), in both cases corresponding to clinical poisoning levels, and suggested that the risk of $\mathrm{Pb}$ poisoning could be specially marked in younger animals.

Iron and copper levels obtained in this study in the investigated blood samples of bulls were high (479.6 ppm for iron and 4.678 ppm for copper) this may be due to interaction with the high levels of lead found in this study. As previous authors reported that lead can interfere with manganese, iron metabolism and may cause anaemia (Sharkawy, 1991 and Miranda et al., 2005). Lead interferes with the metabolism of certain essential elements including copper and iron by affecting their absorption, distribution and bioavailability in the body; and can inhibit DNA protein. $\mathrm{Pb}$ interferes with mitochondrial energy metabolism, which is necessary to reduce ferric iron $\left(\mathrm{Fe}^{3+}\right)$ to ferrous iron $\left(\mathrm{Fe}^{2+}\right)$ before insertion of iron into the porphyrin ring. Swarup et al. (2006) assessed the $\mathrm{Pb}$ burden and status of $\mathrm{Cu}$ and $\mathrm{Fe}$ in the blood of goats reared around a primary lead-zinc smelter and it is concluded from the study that goats reared around a primary lead-zinc smelter had higher blood lead levels that also affected blood copper concentrations in a dose-dependent manner. Liu (2003) reported higher levels of $\mathrm{Pb}$ and $\mathrm{Cd}$ in blood, in sheep and horses, correlating the values with those observed in soil, water, forage and feed in the vicinity of nonferrous metal smelters and suggested that the disease of sheep and horses in that region was caused by $\mathrm{Pb}$ poisoning combined with $\mathrm{Cd}$, as a result of heavy metal pollution by industrial activity. Geens et al. (2010) observed in the study of haemotological status of wintering great tits (Parus major) along a metal pollution gradient, that haemoglobin concentration, haematocrit, mean corpuscular volume and mean corpuscular haemoglobin were lower in great tits from the more polluted sites and as well significantly negatively correlated with blood $\mathrm{Pb}$ concentration.

Our obtained high levels for iron and copper are in agreement with the results recorded by Arslan et al. (2011) who studied trace elements such as $\mathrm{Cu}, \mathrm{Zn}$, and $\mathrm{Fe}$ and levels of heavy metals such as $\mathrm{Cd}$ and $\mathrm{Pb}$ in cattle living at roadsides for at least 3 years and found accumulation of $\mathrm{Cd}$ and $\mathrm{Pb}$ in cattle living near highways. $\mathrm{Cu}$ and $\mathrm{Fe}$ accumulation in cattle raised near highways were higher whereas $\mathrm{Zn}, \mathrm{Cd}$, and $\mathrm{Pb}$ accumulation levels were lower.

\section{Cadmium:}

The recorded $\mathrm{Cd}$ level in the blood of these investigated bulls was $0.1102 \mathrm{ppm}$ which is highly significantly increased when compared with the reference values reported by previous authors. The explanation for this increase may return to increased $\mathrm{Cd}$ concentration as feed and water admitted to these animals. $\mathrm{Cd}$ is accumulated in environment by industrial pollution (Patra et al., 2006 and Swarup et $a l ., 2007)$ which is responsible for soil contamination and also contaminates pasture ( $\mathrm{Yu}$ et al., 2006 and Swarup et al., 2007), because some plants can accumulate this mineral, so this toxic element is ingested by animals grazing these plants or seeds (whole or as meal) (Wang, 2002 and Yu et al., 2006). Copper increases $\mathrm{Cd}$ concentration in organism (Roman et al., 2002). Cd interacts with a number of different trace elements including $\mathrm{Ca}, \mathrm{Cu}, \mathrm{Fe}, \mathrm{Zn}$, proteins, and vitamins $\mathrm{C}$ and $\mathrm{D}$ (NRC, 2005). Perturbation of $\mathrm{Ca}, \mathrm{Zn}$ or Fe homeostasis plays a key 
role in $\mathrm{Cd}$ toxicological action that involves a general threat to basic cellular functions (Goyer, 1995 and Martelli et al., 2006). Cd accumulated in the kidney and liver over long time. It is interacted with numbers of minerals mainly $\mathrm{Zn}, \mathrm{Fe}, \mathrm{Cu}$ and Se due to chemical similarities and competition for binding stage. It is also reported that $\mathrm{Cd}$ causes renal tubules damage, cardiovascular disease, cancer, ostomalacia and also affect calcium, phosphorus and bone metabolism (Radostits, 2000; Wright and Baccarelli, 2007).

Research conducted in an industrialised area of North West Spain, Galicia reported blood concentrations of $\mathrm{Cd}$ in six to ten month old calves and cows (Lopez Alonso et al., 2000). The mean blood Cd concentration was 0.373 and $0.449 \mu \mathrm{g} / \mathrm{l}$ in calves and cows, respectively.

Variable effects of $\mathrm{Cd}$ on $\mathrm{Hb}$ have been reported. Lower doses of dietary $\mathrm{Cd}$ decreased $\mathrm{Hb}$ compared with high doses. The study conducted by Lynch et al. (1976) reported no effect of high concentrations of dietary $\mathrm{Cd}$ on $\mathrm{Hb}$ compared with control calves. Work conducted by Hogan and Jackson (1986) reported that $\mathrm{Cd}$ increased $\mathrm{RBC}$ production in mice. While further work conducted by Hogan and Ranzick (1992) using mice suggests that intraperitoneal Cd, given at a dosage rate of $2 \mathrm{mg} / \mathrm{kg}$ body weight, as a single injection, or at $1 \mathrm{mg} / \mathrm{kg}$ given at 12 or $24 \mathrm{~h}$ intervals, is an effective activator of ALAD, while Cd given at intervals of greater than $24 \mathrm{~h}$ did not affect ALAD, suggesting that duration of exposure may affect the response to $\mathrm{Cd}$. Eosinophilia has also been associated with $\mathrm{Cd}$ intoxication (Martelli et al., 2006).

The high levels of $\mathrm{Cd}$ and $\mathrm{Pb}$ in the current study, may be attributed to the extensive use of these two metals in the Egyptian industry, such as in nickelcadmium batteries, anticorrosive coating of metals, and pigments and stabilizers for plastic. Significant quantities of $\mathrm{Cd}$ and lead are also released from human activities (Baldini et al., 2000; Rahimi and Rokni, 2008), with $90 \%$ of atmospheric Cd and lead emissions coming from anthropogenic sources. These emissions, together with the release of $\mathrm{Cd}$ and lead into aquatic and terrestrial environments, may lead to severe local pollution. Moreover, airborne $\mathrm{Cd}$ and lead may spread widely in the environment by longrange atmospheric transport.

Iron: Iron concentration in the blood of this study was $479.6 \mathrm{ppm}$ which is highly significantly increased when compared with the reference values. This elevation as discussed above may be due to interaction with lead and/or Cd. However, when the levels of these metals in the study areas were compared with values reported in literatures, Nwude et al. (2010a) recorded that Fe levels was found to be about thirty times higher than $1.21 \mathrm{mg} / \mathrm{kg}$ reported, while $\mathrm{Cu}$ in the two studied areas were found to be lower than $0.79 \mathrm{mg} / \mathrm{kg}$.

Copper: Copper concentration in the blood of investigated bulls was $4.678 \mathrm{ppm}$ which is highly significantly increased than the previously mention reference values. Our recorded level for $\mathrm{Cu}$ was in agreement with that observed by the following authors. The range $0.713-1.490$ of $\mathrm{mg} / \mathrm{L}$ obtained for blood $\mathrm{Cu}$ in sample animals falls within a concentration range of $600-1500 \mu \mathrm{g} / \mathrm{L}$ which has been suggested as a critical blood $\mathrm{Cu}$ concentrations in cattle (Erdogan et al., 2004), suggesting contamination of the animals. The cows reared around the contaminated sites had mean blood $\mathrm{Cu}$ concentrations of $984 \mu \mathrm{g} / \mathrm{L}$ respectively which were significantly lower $(\mathrm{P}<0.01)$ than the control values of $17960 \mathrm{mg} / \mathrm{L}$ (Ogundiran et al., 2012).

As recorded by Radostits et al. (2000) and Swarup et al. (2006), if $\mathrm{Pb}$ up to a level of $0.25 \mathrm{ppm}$ in blood is considered safe, above $0.35 \mathrm{ppm}$ is toxic for ruminants; then, the blood $\mathrm{Pb}$ levels observed in this study ( $36.6825 \mathrm{ppm})$ could be said to indicate health risk to the animals under study and consequently to humans who are at the receiving end of the food chain, since the observed values were far higher than the recommended values.

Today, all living organisms and their living environment are constantly exposed to environmental pollutants. Industrial activities are on the rise in parallel with increasing population, and air, soil, and water pollution is endangering the life on earth. Recently built highways and the growing number of vehicles also cause environmental pollution. It has been reported that significant amounts of heavy metals and minerals are discharged into the environment as a result of such industrial activities, and pose a risk to living organisms. The need to reduce trace metals contamination in animal feeds pose a significant problem for agricultural region located in more or less industrialised areas in which animals are reared on locally produced feed. Also a correlation between toxic metals and essential trace elements were evaluated in the blood of sampled cattle. Animals can tolerate elevated levels of heavy metals though at certain levels clinical signs of toxicity manifest which can be acute or chronic at low exposure for a long time.

\section{CONCLUSION}

In conclusion, higher blood heavy metal levels in fattening bulls may present potential health risk to consumers. Hence, there is the need for continued monitoring of blood heavy metal levels in cows.

\section{REFERENCES}

Abd EI-Salam, N.M.; Shabir, A.; Asia, B.; Aisha, K.R.; Ahteram, B.; Riaz, Ullah, Anwar, A.S.; 
Zia, M. and Iqbal, H. (2013): Distribution of heavy metals in the liver, kidney, heart, pancreas and meat of cow, buffalo, goat, sheep and chicken from Kohat market Pakistan, Life Science Journal; 10 (7s).

Arslan, H.H.; Aksu, D.S.; Ozdemir, S.; Yavuz, O.; Or, M.E. and Barutcu, U.B. (2011): Evaluation of the relationship of blood heavy metal, trace element levels and antioxidative metabolism in cattle which are living near the trunk roads. Kafks Univ. Vet. Fak Derg, 17(Suppl A): 77-82.

Ataro, A.; McCrindle, R.I.; Botha, B.M.; McCrindle, C.M.E. and Ndibewu, P.P. (2008): Quantification of trace elements in raw cow's milk by inductively coupled plasma mass spectrometry (ICP-MS). Food Chemistry, 111, 243-248.

Baldini, M.; Stacchini, P.; Cubadda, F.; Miniero, R.; Parodi, P. and Facelli, P. (2000): Cadmium in organs and tissues of horses slaughtered in Italy. Food Additives and Contaminants, 17: 679-687.

Caggiano, R.; Macchiato, M.F. and Ragosta, M. (2004): Heavy metals in ryegrass species versus metal concentrations in atmospheric particulates in an industrial area of southern Italy. Environmental Monitoring and Assessment, 102: 67-84.

Chaney, R.L. (1989): Toxic element accumulation in soils and crops: Protecting soil fertility and agricultural food-chains. In: Bar-Yosef B, Barrow NJ, Goldshmid J (eds.) Inorganic Contaminants in the Vadose Zone. SpringerVerlag. Berlin (Germany). 140-58.

Duruibe, J.; Ogwuegbu, M. and Egwurugwu, J. (2007): Heavy metal pollution and human biotoxic effects. International Journal of Physical Sciences. 2: 112-118.

El-Beltagi, H.S.; Mohamed, A.A. and Rashed, M.M. (2010): Response of antioxidative enzymes to cadmium stress in leaves and roots of radish (Raphanus sativus L.). Notulae Scientia Biologicae. 2: 76-82.

EFSA (European Food Safety Authority) (2004): Opinion of the Scientific Panel on Contaminants in the Food Chain on a request from the Commission related to lead as undesirable substance in animal feed. European Food Safety Authority, 72: 1-24.

EFSA (European Food Safety Authority) (2009): Scientific Opinion of the Panel on Contaminants in the Food Chain: Cadmium in food. EFSA Journal, 2009a, 980: 1-139.

EMEA (European Medicines Agency) (2008): Guideline on the specification limits for residues of metal catalysts or metal reagents. Doc. Ref. EMEA/CHMP/SWP/4446/2000. HTTP://www.emea.europa.eu
Erdogan, S.; Celik, S. and Erdogan, Z. (2004): Seasonal and locational effects of serum, milk, liver and kidney chromium, manganese, copper, zinc and iron concentrations of dairy cows. Bio. Trace Elem., 98: 51-61.

Farr, G. (2004): Why heavy metals are a hazard to your health. http://www.becomehealthynow. com/ebookprint.php?id=1 22 Cited on 26th April 2007.

Geens, A.; Dauwe, T.; Bervoets, L.; Blust, R. and Eens, M. (2010): Haematological status of wintering grits along a metal pollution gradient. Sci.Total Environ., 408: 1174-1179.

Goyer, R.A. (1995): Nutrition and Metal toxicity Am. J. Clin. Nutr, 61(Suppl): 646-650S.

Guidotti, T.; McNamara, J. and Moses, M. (2008): The interpretation of trace element analysis in body fluids. Indian Journal of Medical Research, 128: 524.

Hogan, G.R. and Jackson, P.D. (1986): Dichotomous effects of $\mathrm{Cd}$ and selenium in erythropoiesis in mice. Bull Environ Contam Toxicol., 36: 674679.

Hogan, G.R. and Razniak, S.L. (1992): Split dose studies on the erythropoietic effects of Cd Bull Environ Contain Toxicol., 48: 857-801.

Juhasz, A.L.; Smith, E.; Weber, J.; Rees, M.; Rofe, A.; Kuchel, T.; Sansom, L. and Naidu, R. (2008): Application of an in vivo swine model for the determination of arsenic bioavailability in contaminated vegetables. Chemosphere, 71, 1963-1969.

Kochare, T. and Tamir, B. (2015): Assessment of Dairy Feeds for Heavy Metals. American Scientific Research J. for Engineering, Technology, and Sciences (ASRJETS):11(1): 20-31.

Leggett, R.W. (1993): An age-specific kinetic model of lead metabolism in humans. Environmental health perspectives. 101: 598.

Li, Y.; McCrory, D.F.; Powel, J.M.; Saam, H. and Jackson, S.D. (2005): A survey of selected heavy metal concentrations in Wisconsin Dairy Feeds. Journal Dairy Science 88: 29112922.

Liu, Z.P. (2003): Lead poisoning combined with cadmium in sheep and horses in the vicinity of nonferrous metal smelters. Sci. Total Environ., 309: 117-126.

López Alonso, M.; Benedito, J.L.; Miranda, M.; Castillo, C.; Hernández, J. and Shore, R.F. (2000): Arsenic, cadmium, lead, copper and zinc in cattle from Galicia, NW Spain. The Science of the Total Environment 246, 237248.

Lynch, G.P.; Smith, D.F.; Fisher, M.; Pike, T.L. and Weinland, B.T. (1976): Physiological responses of calves to $\mathrm{Cd}$ and lead. J. Anim Sci., 42 410-421. 
Ma, W.C. (2011): Lead in mammals. In: Beyer NW, Meador JP (eds.) Environmental contaminants in biota -Interpreting tissue concentrations. $2^{\text {nd }}$ ed. CRC Press. Boca Raton, FL (USA). p.595608.

Maas, R.P.; Patch, S.C. and Parker, A. (2002): An assessment of lead exposure potential from residential cutoff valves. Journal of environmental health. 65: 9.

Miranda, M.; Lopez-Alonso, M.; Castillo, C.; Hermandez, J. and Benedito, J.L. (2005): Effects of moderate pollution on toxic and trace metals levels in calves from a polluted area of northern Spain. Environmental Instrumentation. 31, 543-548.

Martelli, A.; Rousselet, E.; Dycke, C.; Bouron, A. and Moulis, J.M. (2006): Cd toxicity in animal cells by interference with essential metals Biochemie 88: 1807-1814

NRC (2005): Mineral Tolerances of Animals, Second Edition. National Academic Press, Washington DC, USA.

Nwude D.O.; Okoye, P.C. and Babayemi, J.O. (2010a): Blood heavy metals levels in cows at slaughter at Awka abattoir, Nigeria. International J of Diary Science, 5(4) 264-270.

Nwude, D.O.; P. C. Okoye, P.C. and J.O. Babayemi, J.O. (2010b): Assessment of accumulation of heavy metals in the kidney of cattle as a function of seasonal variation. Africa Journal of Animal and Biomedical Sciences 5 (3) 1 -8. ISSN: 1819-4214.

Ogabiela, E.E.; Yebpella, G.G.; Adesina, O.B.; Udiba, U.U.; Ade-Ajayi, F.A.; Magomya, A.M.; Hammuel, C.; Gandu, I.; Mmereole, U.J. and Abdullahi, M. (2011): Assessment of Metals Levels in Cow Blood from Cow's Grazed around Zango, Zaria and Challawa Industrial Estate, Kano - Nigeria. J. Appl. Environ. Biol. Sci., 1(4): 69-73.

Ogundiran, M.B.; Ogundele, D.T.; Afolayan, P.G. and Osibanjo, O. (2012): Heavy Metals Levels in Forage Grasses, Leachate and Lactating Cows Reared around Lead Slag Dumpsites in Nigeria. Int. J. Environ. Res., 6(3): 695-702.

Patra, R.C.; Swarup, D.; Sharma, M.C. and Naresh, $R$. (2006): Trace mineral profile in blood and hair from cattle environmentally exposed to lead and cadmium around different industrial units. J. Vet. Med. A53: 511- 517.

Patrick, L. (2006): Lead toxicity, a review of the literature. Part 1: Exposure, evaluation, and treatment. Alternative medicine review : a journal of clinical therapeutic. 11: 2-22.

Payal, B.; Kaur, H.P. and Rai, D.V. (2009): New insight into the effects of lead modulation on antioxidant defense mechanism and trace element concentration in rat bone. Interdisciplinary toxicology. 2: 18-23.
Payne, J. and Livesey, C.T. (2010): Lead poisoning in cattle and sheep. In Pract., 32: 64-69.

Prpić-Majić, D. (1996): Investigation of Lead, Cadmium, and Zinc, in the Meža River Valley, Institut za medicinska istraživanja i medicinu rada, Monografija, Zagreb, Croatia.

Qin, L.Q.; Wang, X.P.; Li, W.; Tong, X. and Tong, W.J. (2009): The minerals and heavy metals in cow's milk from China and. Journal Health Science 55(2): 300-305.

Rahimi, E. and Rokni, N. (2008): Measurement of cadmium residues in muscle, liver and kidney of cattle slaughtered in Isfahan abattoir using grafie furnace atomic absorption spectrometry (GFAAS): a preliminary study. Iranian Journal of Veterinary Research 9: 174-177.

Radostits, O.M.; Blood, D.C; Gay, C.C. and Hinchcliff, H.E. (2000): Veterinary medicine A text book of disease of cattle, sheep, pigs, goats and horses. W.B. Saunders, London.

Radostits, O.M.; Gay, C.C.; Blood, D.C.; Hinchcliff, K.W. and Constable, P.D. (2007): Veterinary Medicine, Saunders Elsevier, Edinburgh, UK.

Rodríguez-Estival, J.; Barasona, J.A. and Mateo, R. (2012): Blood $\mathrm{Pb}$ and $\delta$-ALAD inhibition in cattle and sheep from a $\mathrm{Pb}$-polluted mining area. Environ Pollut 160: 118-124.

Rice-Evans, C. (1990): Iron-mediated oxidative stress and erythrocytes. Erythroid Cells. Springer.

Roman, T.R.N.; Lima, E.G.; Azoubel, R. and Batigália, F. (2002): Toxicidade do cádmio no homem. HB Científica 9: 43-48.

Rumbeiha, W.K.; Braselton, W.E.M. and Donch, D. (2001): A retrospective study on the disappearance of blood lead in cattle with accidental lead toxicosis. Journal Veterinary Clinical Investigations, 13, 373-378.

SCAN (Scientific Committee on Animal Nutrition) (2003): Opinion of the on Undesirable Substances in Feed, adopted on 20 February 2003, updated on 25 April 2003 (http://europa.eu.int/comm/food/fs/sc/scan/ out126_bis_en.pdf); 2003.

Sharkawy, A.A. (1991): Lead levels in macro- and microenvironment of cattle at Assiut Governorate. Master Thesis of Veterinary Sciences. Fac. Vet. Medicine, Assiut University, Assiut, Egypt.

Solidum, J.M.; De Vera, M.J.D.; Ar-Raquib, D.C. Abdulla, J.H.E. and Nerosa, M.J.V. (2013): Quantitative Analysis of Lead, Cadmium and Chromium found in Selected Fish marketed in Metro Manila, Philippines, International $\mathbf{J}$ of Environmental Science and Development; 4 (2).

SPSS (2001): "Statistical software package for the social sciences." SPSS Inc. United States of America. Cited by http://www.spss.com.

Swarup, D.; Patra, RC.; Naresh, R.; Kumar, P. and Shekhar, P. (2005): Blood lead levels in lactating cows reared around polluted 
localities; transfer of lead in to milk. Science of the Total Environment, 347: 106-110.

Swarup, D.; Patra, R.C.; Naresh, R.; Kumar, P.; Shekhar, $P$. and Baragangatharathilagar, $M$. (2006): Lowered blood copper and cobalt contents in goats reared around lead-zinc smelter. Small Ruminant Res., 63: 309-313.

Swarup, D.; Naresh, R.; Varshney, VP.; Balagangatharathilagar, M.; Humar, P.; Nandi, D. and Patra, R.C. (2007): Changes in palsma hormones profile and liver function in cows naturally exposed to lead and cadmium around different industrial areas. Res. Vet. Sci. 82: $16-21$

Thuppil, V. and Tannir, S. (2013): Treating Lead Toxicity: Possibilities beyond Synthetic Chelation. Journal of Krishna Institute of Medical Sciences University. 2: 4-31.
Wang, K.R. (2002): Tolerance of cultivated plants to cadmium and their utilization in polluted farmland soil. Acta Biotechnol. 22: 189-198.

Ward, N.I. and Savage, J.M. (1994): Element status of grazing animals located adjacent to the London Orbital (M25) motorway. Sci. Total Environ, 146: 185-189.

Wright, R.O. and Baccarelli, A. (2007): Metals and neurotoxicology. J of Nutrition, 137(12): 2809-2813.

Whitehurst, B. (2015): Mineral Supplementation of Beef Cattle in the Pacific Northwest. A Pacific Northwest Extension Publication, University of Idaho. Oregon State University. Washington State University. PNW 670, p.1-9.

Yu, H.; Wang, J.; Fang, W.; Yuan, J. and Yang, Z. (2006): Cadmium accumulation in different rice cultivars and screening for pollution-safe cultivars of rice. Sci. Total Environ. 370: 302309.

\section{تقييم بعض العناصر الثقيلة وصورة الام فى عجول التسمين فى محافظة أسيوط$$
\text { أحد عبد الباقى شرقاوى ، سحر أحمد أبو الوفا }
$$

E-mail: dsaharahmed2003@yahoo.co.uk Assiut University web-site: www.aun.edu.eg

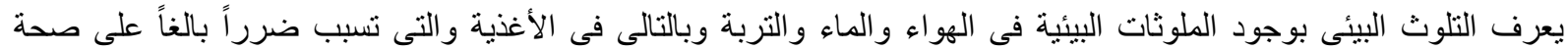

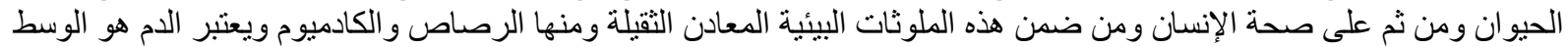

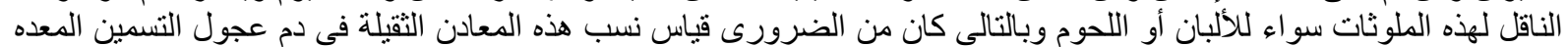

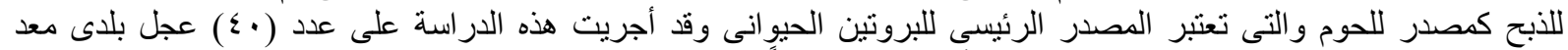

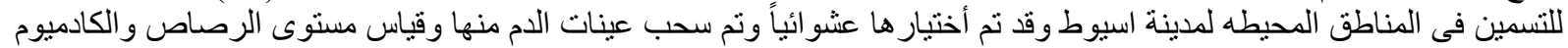

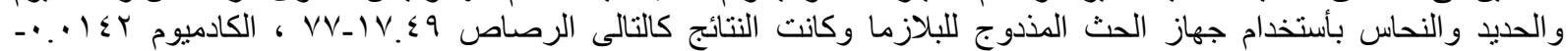

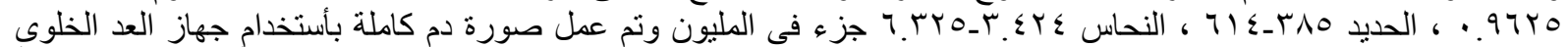

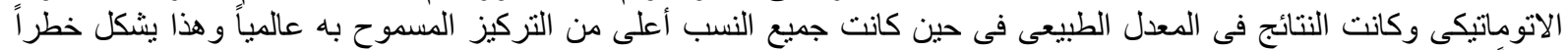

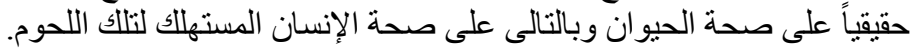

